\title{
Long-term Changes of Disinfection Byproducts in Treatment of Simulated Ballast Water
}

\author{
Pung-Guk Jang* and Hyung-Gon Cha \\ Ballast Water Research Center, South Sea Research Institute, Korea Institute of Ocean Science \& Technology, Geoje 53201, Korea
}

Received 26 September 2019; Revised 9 February 2020; Accepted 13 February 2020

(C) KSO, KIOST and Springer 2020

\begin{abstract}
This study investigated the changes in concentrations of haloacetic acids (HAAs) and haloacetonitriles (HANs) as disinfection byproducts (DBPs) for different storage times (as long as 20 days) and temperatures $\left(5\right.$ to $\left.20^{\circ} \mathrm{C}\right)$. A ship's voyage after treatment of its ballast water with active substances was considered. The HAA showed a clear trend of increasing concentration only with storage time, especially for dibromoacetic acid (DBAA). Dissolved organic nitrogen concentration was increased by the decomposition of dead organisms at 10 days, and then reacted with the remaining total residual oxidants, resulting in increased concentration of DBPs. An environmental risk assessment indicated that DBAN and monochloroacetic acid (MCAA) could have a negative impact on the marine environment. This study suggests that, because all international vessels must have a ballast water management system installed by September, 2024, the concentrations of DBPs, especially DBAN, MCAA, and DBAA, should be monitored in the waters at major international ports.
\end{abstract}

Keywords - disinfection byproducts, ballast water management system, active substances, ballast water, dissolved organic nitrogen

\section{Introduction}

"Ballast water" refers to water entering a ship to provide stability during navigation. Global ballast water discharged from ongoing vessels engaged in international trade has been estimated to exceed 3 billion tons per year (Endresen et al. 2004; David 2018). When water is loaded as ballast water from a ship's surrounding environment, suspended matter and living organisms are also taken onboard. When they are discharged in the next port, some transferred species can settle and flourish, potentially adversely affecting the environment, human health, and the economy associated with the recipient

\footnotetext{
*Corresponding author. E-mail: pgjang@kiost.ac.kr
}

environments (Hallegraeff and Bloch 1991; Pimentel et al. 2005; Gollasch 2006). To regulate discharged ballast water, the International Maritime Organization (IMO) established the International Convention for the Control and Management of Ship's Ballast Water and Sediments (BWM Convention) in 2004, which aimed to minimize the movement of harmful organisms and pathogens via ballast water (IMO 2004). The BWM Convention requires that qualified vessels be installed with a flag-state-certified ballast water management system (BWMS). The Convention established the ballast water discharge requirement as regulation D-2 and requires the installation of a BWMS before September 8, 2024, in accordance with regulation B-3 of the Convention.

Technologies used for BWMSs include electrolysis, ultraviolet irradiation, ozonation, filtration, and thermal treatment. Among these technologies, a electrolysis is the most widely used method because of its efficiency and cost effectiveness (Duan et al. 2016). As of January, 2019, electrolysis systems accounted for $45 \%$ of BWMSs approved by flag states (IMO 2019). Free chlorine is generated during electrolysis of salts in water. Chlorine can rapidly oxidize bromide ion $\left(\mathrm{Br}^{-}\right)$and iodide ion $\left(\mathrm{I}^{-}\right)$to form aqueous bromine $(\mathrm{HOBr} / \mathrm{OBr})$ and aqueous iodine (HOI/OI'), respectively (Westerhoff et al. 2004). The bromide ion, in concentrations of $60-70 \mathrm{mg} / \mathrm{L}$ in seawater, gives a high formation potential of bromine ( $\mathrm{HOBr} /$ $\mathrm{OBr}$ ) which is the main active substance in chlorinated seawater. In seawater with a typical $\mathrm{pH}$ of 8 , hypobromous acid (HOBr) will predominate and be the most important disinfectant with a half-life of hours to days dependent on light conditions and water quality characteristics (Liltved et al. 2006). The sum of persistent oxidants is collectively referred to as total residual oxidant (TRO). The TRO disintegrates 
over time, but it is sufficiently stable to react with and kill or inactivate organisms. However, the TRO produced by electrolysis can generate residues and reacts with organic matter in water to produce disinfection by-products (DBPs) which can adversely affect marine ecosystems (Delacroix et al. 2013; Werschkun et al. 2014; Cha et al. 2015; Gonsior et al. 2015; Lee et al. 2017; David et al. 2018). Therefore, BWMSs that use active substances, including chlorine, must be approved by the Marine Environment Protection Committee (MEPC) according to regulation G9 of the Convention.

In studies of the chlorination of freshwater for drinking water, numerous problems have been reported. One issue is the formation of DBPs, which have been known since the 1970 s to potentially adversely affect human health (Gonsior et al. 2015). Classes of DBPs observed in chlorinated water include trihalomethanes (THMs), haloacetic acids (HAAs), haloacetonitriles (HANs), halonitromethanes (HNMs), haloketones (HKs), and chloral hydrate. Although DBPs associated with the freshwater chlorination of drinking water have long been a topic of research, studies of the effects of the formation of DBPs by brackish or seawater chlorination have recently become more common because of increased interest in ballast water treatment and seawater desalination (Delacroix et al. 2013; Cha et al. 2015; Gonsior et al. 2015; Shah et al. 2015; Lee et al. 2017; Park et al. 2017; David et al. 2018). The formation of DBPs is considered problematic in oxidizing-water disinfection (von Guntten 2018). The amount of organic DBPs in chlorinated ballast water is mainly dependent on the oxidant type and dosage and on the type and concentration of natural organic matter in the local ballast water (Gonsior et al. 2015; Shah et al. 2015; Liu et al. 2018). In addition, the type and concentration of DBPs during seawater disinfection have been found to depend on the temperature, salinity, bromide, iodide and the $\mathrm{pH}$ (Hua et al. 2006; Zhang et al. 2013b; Kim et al. 2015; Shah et al. 2015; Cha et al. 2015; Yu et al. 2015). Thus, the environmental changes in the tank where ballast water treated with BWMS are stored can affect DBP concentrations.

As previously mentioned, various factors play important roles in determining the type and concentration of DBPs; however, the type and concentration of DBPs can be changed by the active substances remaining during storage in the tank of the vessel after treatment. The temperature and storage time of water stored in a ballast tank also affect the concentration and type of DBPs (Drillet et al. 2013; Zhang et al. 2013a; Shah et al. 2015). The temperature variation of ballast water shows a seasonal pattern. For example, Choi et al. (2005) found greater variation in the mid-ocean upon exchange (2$\left.28^{\circ} \mathrm{C}\right)$ than in samples collected upon arrival $\left(11-25^{\circ} \mathrm{C}\right)$ in the San Francisco Estuary. The water temperature in the ballast water of ships entering ports in Korea was found to sometimes be higher than the water temperature of the port by approximately $1-2^{\circ} \mathrm{C}$, although this difference reflects the seasonal changes in water temperature of the marine environment(Jang etal.2016; Hyunetal.2017). Infreshwater, an increase in temperature results in faster consumption of total residual oxidants (TROs) or chlorine, leading to a positive correlation with several DBPs, especially THMs and HAAs (Roccaro et al. 2008; Zhang et al. 2013b). With faster decay of the active substances for disinfection in warm water, a neutralizing agent may not be required in a warmer area, whereas it may be a necessity in colder waters (Drillet et al. 2013). The remaining TROs in the ballast water tank would continue to kill the organisms and produce new DBPs, depending on the remaining TRO concentrations. Shah et al. (2015) reported that approximately $50 \%$ of the DBPs formed within a 24-h period of the typical 5-day inspection period, which is a typical storage time for the BWMS-type approval test described in the IMO G9 guidelines. According to the IMO G9 guidelines, for a BWMS that uses active substances to be approved, it should be subjected to ecotoxicological testing and DBPs of the treated ballast water from test cycles with a storage time shorter or longer than five days should be chemically assessed for at least one test cycle per salinity in land-based testing (IMO 2008). Thus, the test period in studies of DBPs and residual active substances related to BWMSs has typically been 5 days (Zhang et al. 2013a, 2013b; Cha et al. 2015; Shah et al. 2015; Lee et al. 2017).

International vessels arriving in ports of Korea take approximately 18 to 24 days to arrive in Busan from the eastern and northern Europe and approximately 11 to 22 days from the western and eastern United States. In the case of neighboring countries such as Japan, China, and Russia, arrival within 1 day is possible. As a result, changes in the DBP concentration and the environmental risk should be evaluated based on consideration of the water storage temperature and storage time in a ship's ballast water tank. Therefore, the aim of this paper was to investigate the changes in DBPs concentrations and to assess the environmental risks of their concentration changes according to possible variation of storage temperature and time. 


\section{Materials and Methods}

\section{Preparation of test water for electrochlorination}

To evaluate the performance of a BWMS with an electrolytic device, tests were carried out at test facilities for type approval of a BWMS; these facilities were located at the South Sea Research Institute of the Korea Institute of Ocean Science \& Technology in Korea. The main sterilization device of the BWMS was an electrolytic device with a filter system on the front end. These devices were installed directly in the ballastwater pipeline. Seawater was transferred by the ballast water pump to the 500 ton tank of the facility in Jangmok Bay. The water flow was adjusted to $300 \mathrm{~m}^{3} \mathrm{~h}^{-1}$. The electrolysis system $\left(15.0 \pm 1.5 \mathrm{mg} \mathrm{L}^{-1}\right.$ as $\left.\mathrm{Cl}_{2}\right)$ killed remaining organisms in the water. The treated water was stored in the treated sampling tank (250 tons) for 5 days in the absence of light. The challenge water was produced in accordance with the code for approval of BWMS (IMO 2018a). The addition of chemical and biological constituents was minimal (ideally $<25 \%$ of the total concentration of any constituents in the raw water) before the ballasting test. Natural organisms were added directly into the 500 ton tank of the facility to satisfy the condition of natural sea water. Glucose, starch, and silica were supplied to satisfy the condition of dissolved organic carbon (DOC), particle organic carbon (POC), and total suspended solids (TSS), in accordance with the G8 guidelines. The conditions of the challenge water are shown in Table 1. One ton of the treated water was continuously sampled in the sampling tank as the 300 tons of challenge water treated by the BWMS was transferred to the treated tank over a period of approximately $1 \mathrm{~h}$. In a well-mixed 1 ton continuous sampling tank, subsamples were transferred to $3 \mathrm{~L}$ sterile bags stored in each incubator setup. The temperature of the incubator was set at $5,10,15$, and $20^{\circ} \mathrm{C}$, and the sample from each sterile bag was analyzed on Day 1, Day 5, Day 10, and Day 20, taking into account the storage time. To examine the effect of additives on the dissolved organic nitrogen (DON) concentration and TRO decay, test waters were prepared at $20^{\circ} \mathrm{C}$ from filtered seawater, filtered seawater with added glucose, filtered seawater with added phytoplankton, and filtered seawater with both added glucose and added phytoplankton.

\section{Water-quality parameters and DBPs production}

Water temperature, salinity, and dissolved oxygen were measured in situ with a YSI6600 water-quality measurements apparatus (YSI, Yellow Springs, Inc.). The concentrations of dissolved nitrogen (DN), nitrate, nitrite, and ammonia were measured using a flow injection autoanalyzer (QuAAtro; Seal Analytical, Inc., UK). The DN, nitrate, nitrite, and ammonia were repeatedly analyzed with an accuracy of $97 \%$ or better. Dissolved inorganic nitrogen (DIN) was calculated as the sum of the nitrate, nitrite, and ammonia concentrations. The DON value was obtained by subtracting the DIN value from the DN value. A pocket Colorimeter ${ }^{\mathrm{TM}}$ II analysis system (Hach Co., Loveland, CO, USA) was used to measure the TRO concentration in conjunction with the $N, N$-diethyl- $p$ phenylenediamine (DPD) method, which formed a red solution. Samples for analysis of the DOC were gravity filtered directly from a glass syringe. Water was filtered before acidification to $1 \leq \mathrm{pH} \leq 2$ with $\mathrm{H}_{3} \mathrm{PO}_{4}$ or $\mathrm{H}_{2} \mathrm{SO}_{4^{-}}$. Immediately after acidification, the sample was frozen to a temperature of less than $-20^{\circ} \mathrm{C}$ and was analyzed within $14 \mathrm{~d}$ of sampling. Analysis of the DOC was carried out using a TOC analyzer (TOC- $\mathrm{V}_{\mathrm{CPH}}$, Shimadzu Co.). Adequate volumes of samples for particulate organic carbon (POC) and particulate organic nitrogen (PON) were filtered onto precombusted $25 \mathrm{~mm}$ Whatman GF/F filters. The filters were removed, placed in capsular tissue, wrapped in aluminum foil, and stored frozen in a deep freezer $\left(-20^{\circ} \mathrm{C}\right)$ until analyzed. Analyses of the POC and PON were carried out using a FlashEA ${ }^{\mathrm{TM}} 1112$ elemental analyzer (ThemoQuest, Inc.).

The DBPs were analyzed for nine HAAs and six HANs of the 41 chemical substances related to the BWMS, as defined in the MEPC 67/INF.17 document by the Marine Environment Protection Committee (MEPC) of the IMO (MEPC 2014). The nine species of HAAs were bromochloroacetic acid (BCAA), dibromoacetic acid (DBAA), dichloroacetic acid (DCAA), dibromochloroacetic acid(DBCAA), dichlorobromoacetic acid(DCBAA), monobromoacetic acid(MBAA), monochloroacetic acid (MCAA), tribromoacetic acid (TBAA), trichloroacetic acid(TCAA); the six species of HANs were trichloroacetonitrile (TCAN), monochloroacetonitrile (MCAN), dichloroacetonitrile

Table 1. Physical, chemical and biological parameters of the test water

\begin{tabular}{|c|c|c|c|c|c|}
\hline \multicolumn{2}{|c|}{ Physical parameters } & \multicolumn{2}{|c|}{ Chemical parameters $\left(\mathrm{mg} \mathrm{L}^{-1}\right)$} & \multicolumn{2}{|c|}{ Biological parameters } \\
\hline Temp. $\left({ }^{\circ} \mathrm{C}\right)$ & $11.10 \pm 0.13$ & TRO & $14.30 \pm 0.9$ & \multirow{2}{*}{$\begin{array}{c}>50 \mu \mathrm{m} \text { organism } \\
\left(\text { cells ton }^{-1}\right)\end{array}$} & \multirow{2}{*}{$111,667 \pm 15,275$} \\
\hline Sal. & $33.10 \pm 0.17$ & POC & $10.40 \pm 1.04$ & & \\
\hline $\mathrm{pH}$ & $8.06 \pm 0.02$ & DOC & $8.04 \pm 0.30$ & \multirow{2}{*}{$\begin{array}{c}10-50 \mu \mathrm{m} \text { organism } \\
\left(\text { cells } \mathrm{mL}^{-1}\right)\end{array}$} & \multirow{2}{*}{$3017 \pm 136$} \\
\hline Turbidity (NTU) & $5.70 \pm 2.33$ & TSS & $53.60 \pm 2.97$ & & \\
\hline
\end{tabular}


(DCAN), monobromoacetonitrile (MBAN), bromochloroacetonitrile (BCAN), and dibromoacetonitrile (DBAN). The HAA and HAN concentrations were determined on a gas chromatography electron-capture-detector system (Agilent 6890N). A DB1701 column ( $30 \mathrm{~m}$ long, $0.32 \mathrm{~mm}$ i.d., $0.25 \mu \mathrm{m}$ stationary phase) was used for the HAAs and HANs. The HAA and HAN standards were Accustandards (New Haven, CT, USA) in solid form. All reagents used for extraction were highperformance liquid chromatography (HPLC) grade or better. The method detection limit (MDL $=t \times \sigma$, where $\sigma$ is the standard deviation of the data and $t$ is the compensation factor from the Student's t-test with $n-1$ degrees of freedom at a confidence interval of $95 \%$ ) and the method quantification limit (MQL $=10 \times \sigma$, where $\sigma$ is the standard deviation of the data) were estimated using a lower spike concentration. Relative standard deviations (RSDs) of laboratory control samples (LCSs) of the compounds used in constructing the calibration curves met the condition $|\mathrm{RSD}|<15 \%$.

\section{Environmental risk assessment and statistical analysis}

The person correlation coefficient was calculated using the statistical program SPSS 18.0 to analyze the effect of time and temperature variation on the HAA and HAN concentrations. The GESAMP-Ballast Water Working Group (BWWG) approval process for BWMSs considers the environmental acceptability of the BWMS, including modeling-predicted DBP concentrations in a standardized port environment with a set discharge volume. The GESAMP is a group of independent scientific experts that provide the UN with information on the scientific aspects of marine environmental protection. The marine antifoulant model to predict environmental concentrations (MAMPEC) was used by GESAMP-BWWG to assess the potential for environmental impacts from BWMSs during the type approval test. The environmental risk index was calculated and evaluated for the possibility that the DBP could be hazardous to the environment assuming both general and near-ship conditions. The predicted environmental concentration (PEC) was calculated by applying the commercial trade port (GESAMP-BWWG model harbor) installed in the MAMPEC 3.1 model. The highest value of each HAA and HAN was used in all of the tests to calculate the PEC value. For the predicted no-effect concentration (PNEC), we used the value provided by IMO GISIS (ballast water chemicals) to collect ecotoxicity information about each chemical. If the PEC/PNEC ratio in general and near ship was 1 or greater, as determined by calculating the PEC and the PNEC for each DBP detected above the detection limit, then the DBP was considered potentially harmful in the environment.

\section{Results}

\section{Changes in environmental factors in test water}

Temporal variations in the TRO, DON, and DIN concentrations were measured for each storage time and temperature, and the temporal variations of the DOC, POC, and PON were measured at $20^{\circ} \mathrm{C}$ (Fig. 1). The TRO concentration was 15.2 $\mathrm{mg} \mathrm{L}^{-1}$ at Day 0 and ranged from 1.78 to $6.3 \mathrm{mg} \mathrm{L}^{-1}$ at $5^{\circ} \mathrm{C}$, from 0.48 to $6.4 \mathrm{mg} \mathrm{L}^{-1}$ at $10^{\circ} \mathrm{C}$, from 0.13 to $6.30 \mathrm{mg} \mathrm{L}^{-1}$ at $15^{\circ} \mathrm{C}$, and from 0.08 to $5.1 \mathrm{mg} \mathrm{L}^{-1}$ at $20^{\circ} \mathrm{C}$ during Day 1 to Day 20 , respectively. The TRO concentration remained high at lower water temperatures. The total DON ranged from 2.94 to $17.96 \mu \mathrm{g} \mathrm{L}^{-1}$ (mean \pm standard deviation: $8.21 \pm 4.50 \mu \mathrm{g} \mathrm{L}^{-1}$ ), which was the highest at all water temperatures on Day 10 . At relatively low water temperatures $\left(5\right.$ and $\left.10^{\circ} \mathrm{C}\right)$, the initial DON concentration was high, and this tendency was observed until Day 10 . The DIN ranged from 0.99 to $\left.2.14 \mu \mathrm{g} \mathrm{L}^{-1}(1.41 \pm 0.31 \mu \mathrm{g} \mathrm{L})^{-1}\right)$ and reached a maximum value at 10 days, similar to the DON. The DOC, POC, and PON ranged from 7.26 to $8.20 \mathrm{mg} \mathrm{L}^{-1}$ ( $\left.7.27 \pm 0.38 \mathrm{mgL}^{-1}\right)$, from 2.17 to $2.79 \mathrm{mgL}^{-1}\left(2.51 \pm 0.28 \mathrm{mgL}^{-1}\right)$, and from 0.01 to $0.07 \mathrm{mgL}^{-1}\left(0.05 \pm 0.03 \mathrm{mg} \mathrm{L}^{-1}\right)$, respectively. The DIN concentrations tended to increase and decrease at low temperatures $\left(5^{\circ} \mathrm{C}\right.$ and $\left.10^{\circ} \mathrm{C}\right)$, to not change at $15^{\circ} \mathrm{C}$, and to show a parabolic trend at $20^{\circ} \mathrm{C}$. The DOC and PON tended to decrease with increasing storage time, whereas the POC did not show any significant change with increasing storage time.

To determine the source of the DON concentration, four experiments were carried out at $20^{\circ} \mathrm{C}$ to monitor the change in the DON concentration over time (Fig. 2a). The increase in DON concentration was more pronounced in the experiments with the filtered seawater with added phytoplankton (Group 3 ) and the filtered seawater with added phytoplankton and glucose (Group 4) than in the filtered seawater blank (Group 1) and the filtered seawater with added glucose (Group 2). In Groups 3 and 4, the DON increased; Group 4 exhibited the highest DON value at 7 days, whereas Group 3 exhibited the highest DON value at 10 days. Group 2 showed a slightly higher DON concentration than Group 1, but no significant difference was observed. In addition, the group with the fastest TRO decay among these test groups was Group 4, followed by Groups 2, 3, and 1 (Fig. 2b). In particular, the TRO concentration was high $\left(7.60 \mathrm{mg} \mathrm{L}^{-1}\right)$ even after 17 

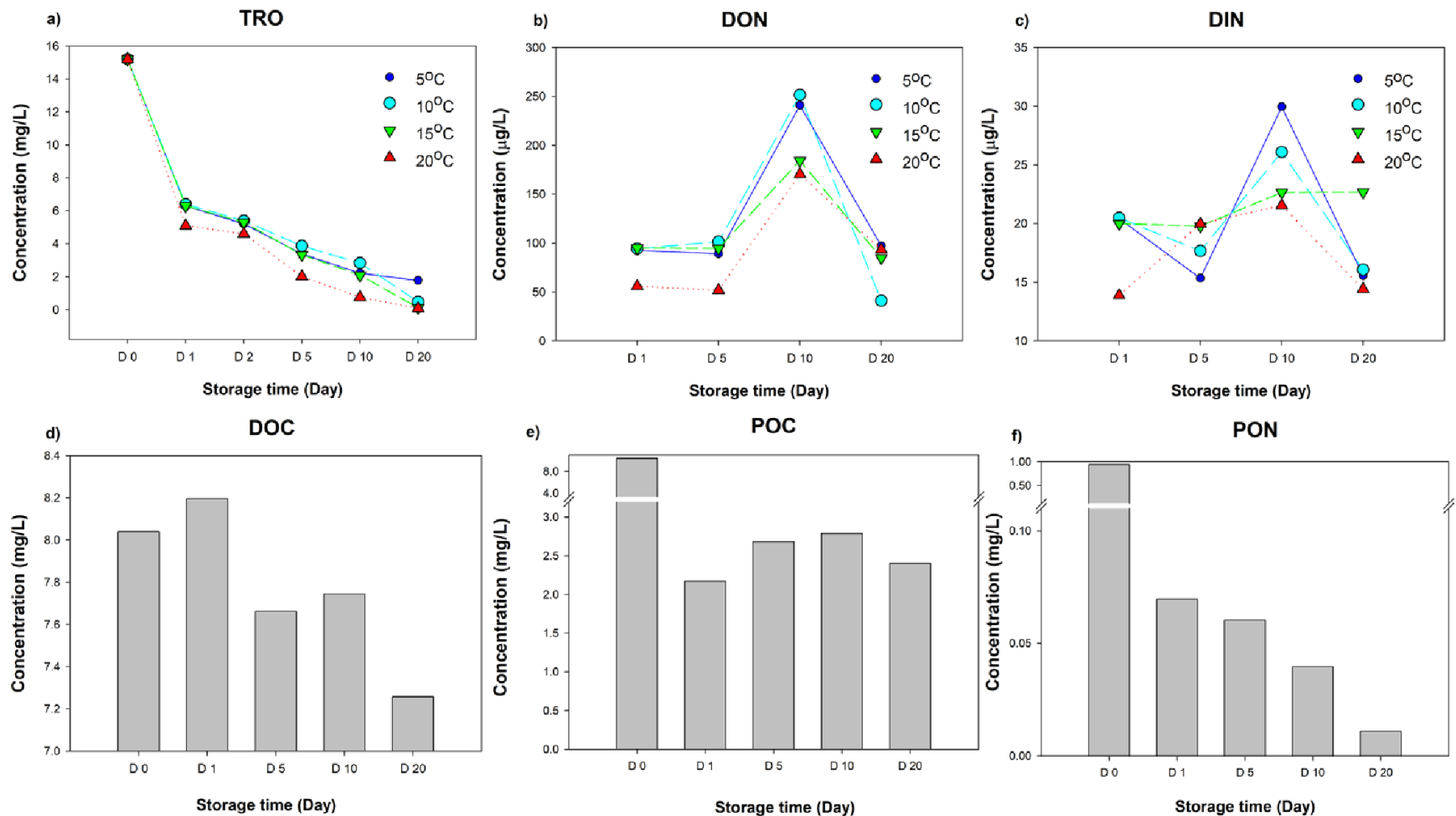

Fig. 1. Concentration changes of the (a) total residual oxidants (TRO), (b) dissolved organic nitrogen (DON), and (c) dissolved inorganic nitrogen (DIN) as functions of time at various temperatures in each test water. Concentration changes of the (d) dissolved organic carbon (DOC), (e) particulate organic carbon (POC), and (f) particulate organic nitrogen (PON) as functions of time at $20^{\circ} \mathrm{C}$
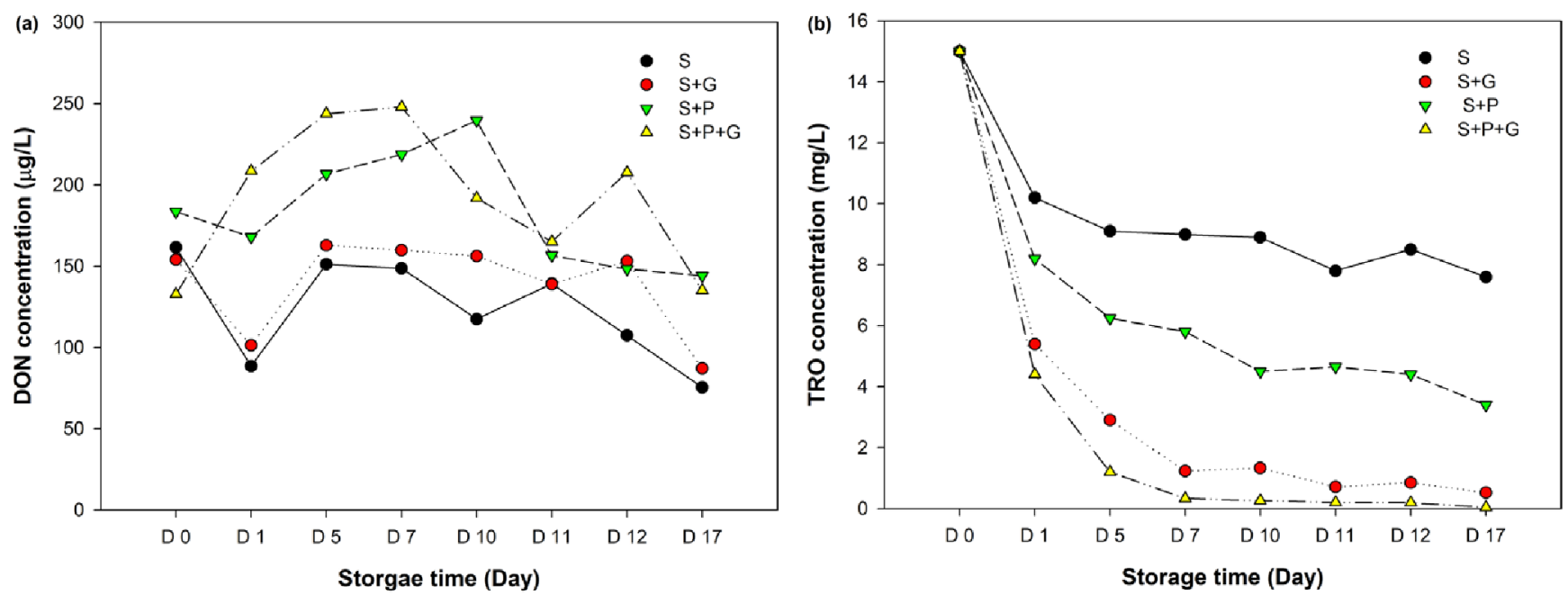

Fig. 2. Concentration changes of (a) the dissolved organic nitrogen (DON) and (b) the total residual oxidants (TRO) as functions of time at $20^{\circ} \mathrm{C}$. (S: filtered seawater, $\mathrm{S}+\mathrm{G}$ : filtered seawater with glucose added: $\mathrm{S}+\mathrm{P}$ : filtered seawater with phytoplankton added, $\mathrm{S}+\mathrm{P}+\mathrm{G}$ : filtered seawater with both phytoplankton and glucose added)

days in the case of filtered seawater to which organic matter and organisms were not added.

\section{Changes in DBPs in test water}

In the variation of the storage time, the total concentrations of HAAs and HANs were not significantly different between
Day 1 and Day 5; however, after 5 days, the concentrations of HAAs were relatively higher than those of HANs (Fig. 3a). The total HAA concentration was 4.5 times higher than the total HAN concentration on Day 20 (Fig. 3a). The mean values of the HAA and HAN concentrations at various water temperatures were the highest at $10^{\circ} \mathrm{C}($ Fig. $3 \mathrm{~b})$. However, 

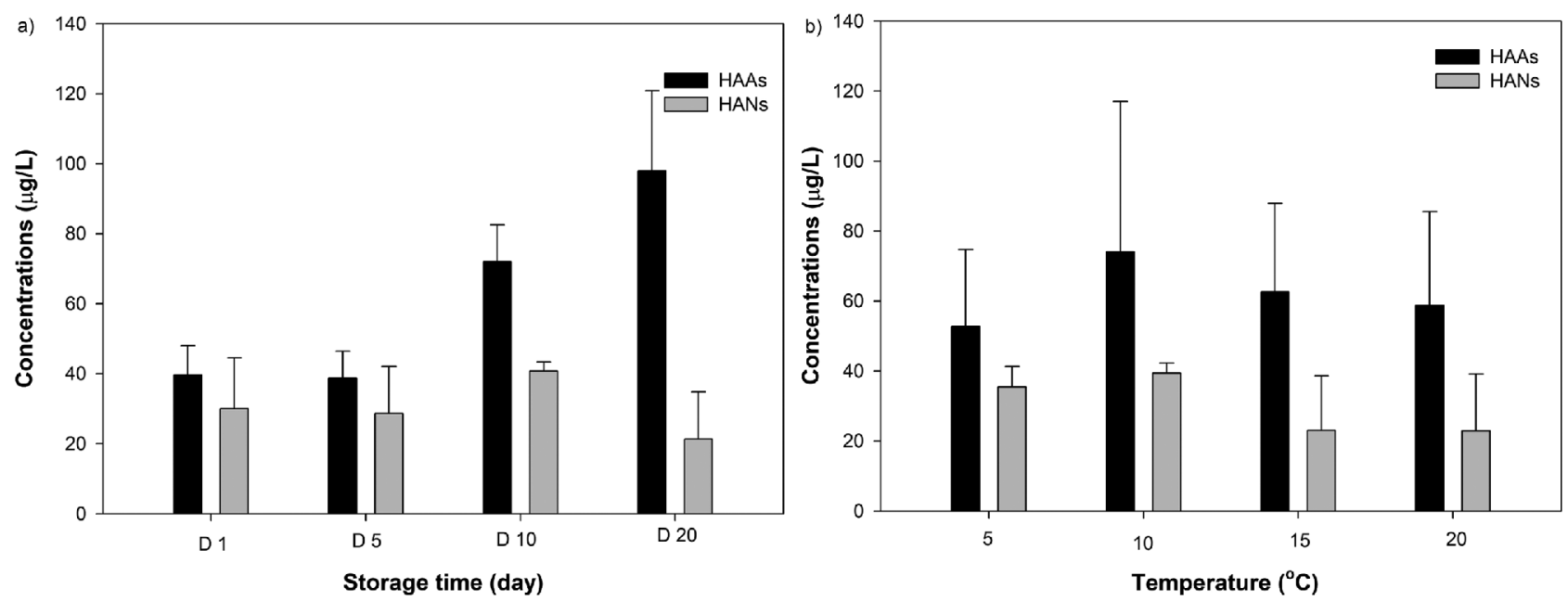

Fig. 3. Effects of (a) the storage time and (b) the storage temperature on the formation of HAAs and HANs

the variation of the total HAA concentration for each water temperature was large; it therefore did not show a clear trend with respect to water temperature. Although the variation of total HAN concentration was large at high temperatures, the total concentration of the HANs at low temperatures ( 5 and $10^{\circ} \mathrm{C}$ ) was more than two times greater than that of the HANs at high temperatures $\left(15\right.$ and $\left.20^{\circ} \mathrm{C}\right)$.

A total of fifteen HAA and HAN species were analyzed in
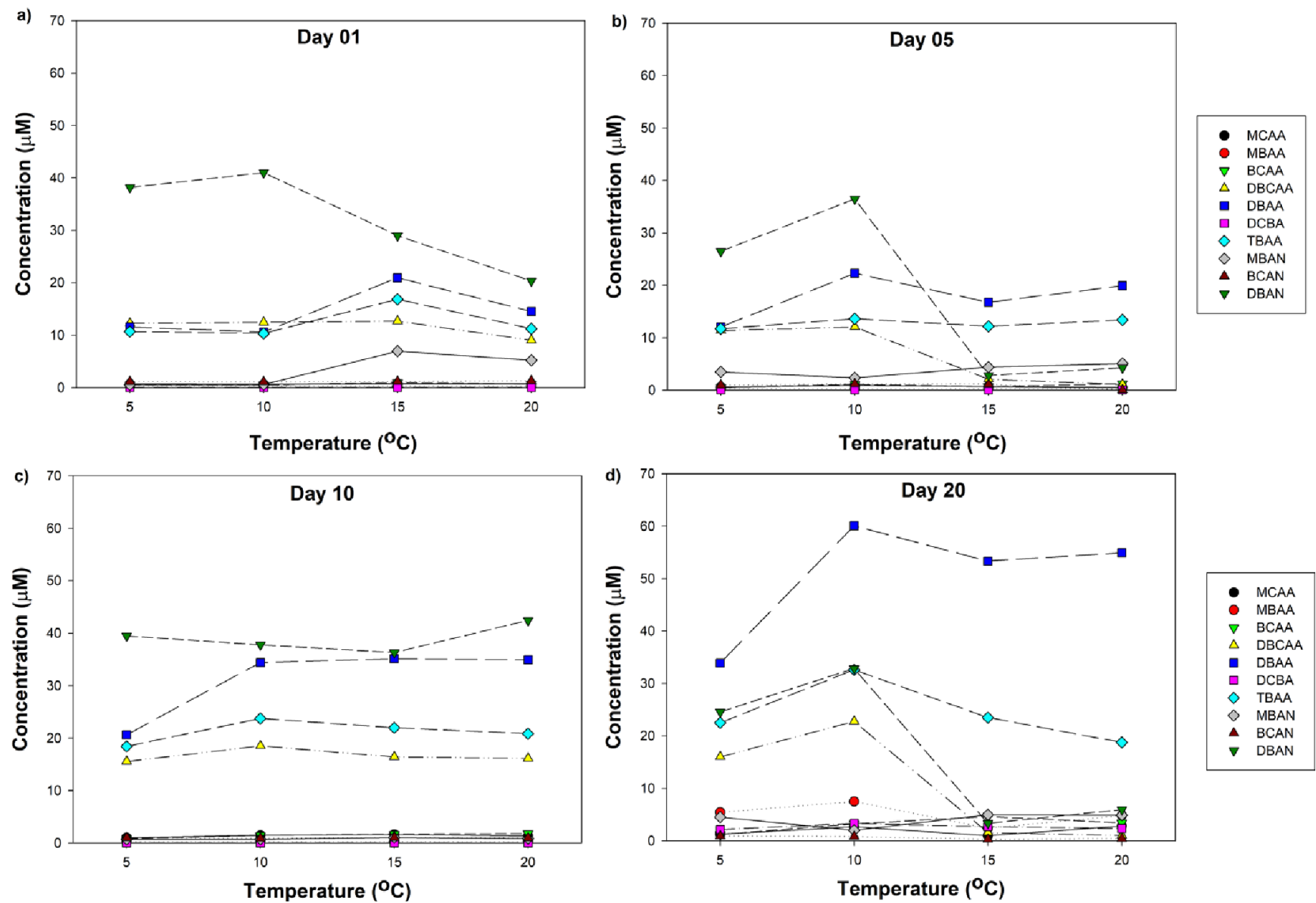

Fig. 4. Changes in concentration of 10 DBPs (HAAs and HANs) with increasing storage time and at various water temperatures 
this study. Seven species (MCAA, MBAA, BCAA, DBCAA, DBAA, DCBAA, and TBAA) of the analyzed HAAs and three species (BCAN, DBAN, and MBAN) of the analyzed HANs were present at concentrations above their detection limits. The concentrations of the other HAAs and HANs were
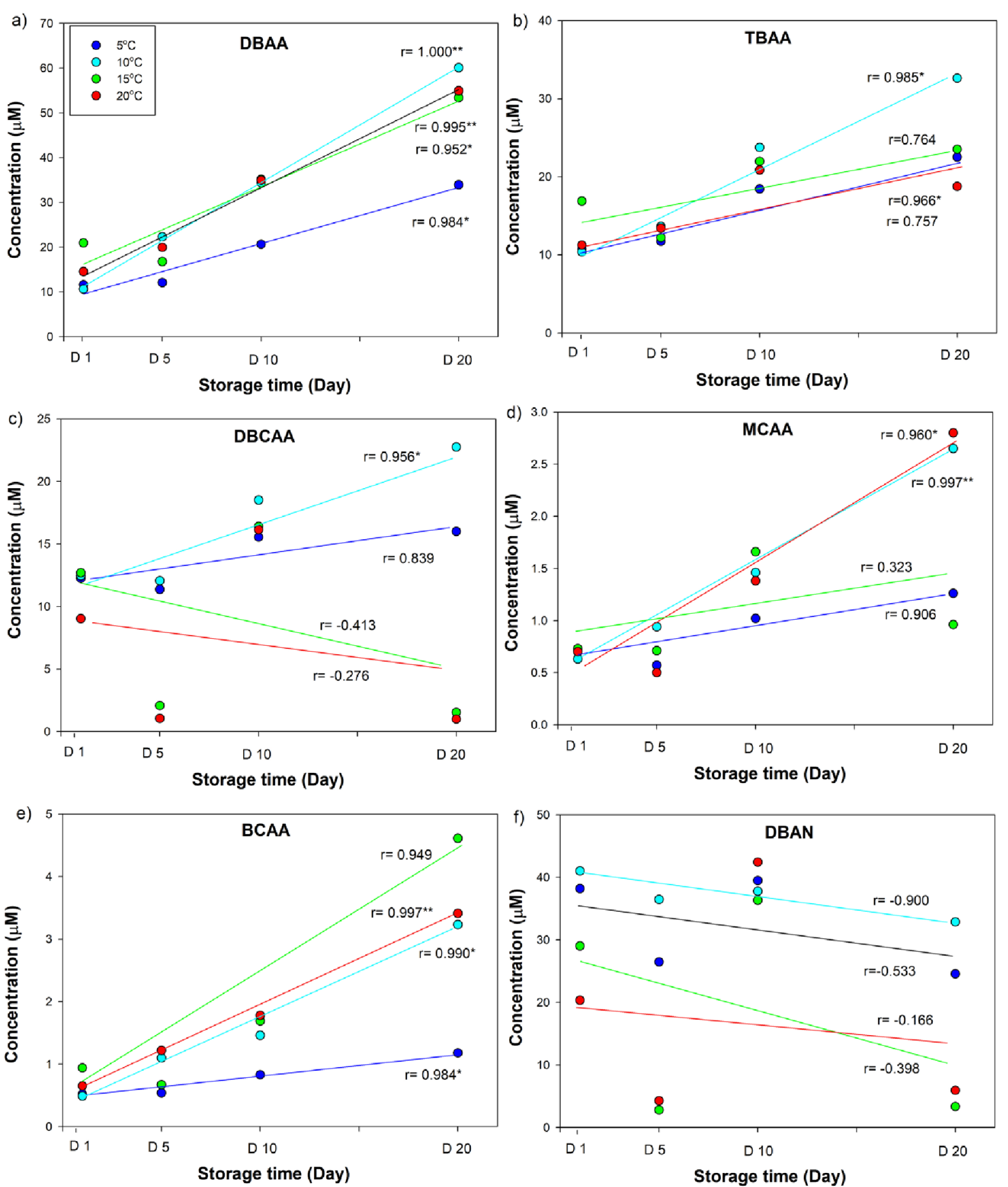

Fig. 5. Pearson relationships for storage time and storage water temperature of major DBPs $\left({ }^{*} p<0.05, * * p<0.01\right)$. (DBAA: dibromoacetic acid, TBAA: tribromoacetic acid, DBCAA: dibromochloroacetic acid, MCAA: monochloroacetic acid, BCAA: bromochloroacetic acid, DBAN: dibromoacetonitrile)

below their detection limits. Among these DBPs analyzed, DBAA, DBCAA, TBAA, and DBAN were formed at considerable concentrations of $10 \mu \mathrm{g} \mathrm{L}{ }^{-1}$ or higher. Specifically, the DBAA, DBCAA, TBAA, and DBAN concentrations were in the ranges $10.6-60.1 \mu \mathrm{g} \mathrm{L}^{-1}, 0.99-22.8 \mu \mathrm{g} \mathrm{L}{ }^{-1}, 10.4-$ 
32.6 $\mu \mathrm{g} \mathrm{L}^{-1}$, and 2.78-42.4 $\mu \mathrm{g} \mathrm{L}{ }^{-1}$, respectively (Fig. 4). The MCAA, BCAA, and MBAN concentrations ranged from 0.5 to $2.8 \mu \mathrm{g} \mathrm{L}{ }^{-1}$, from 0.54 to $4.61 \mu \mathrm{g} \mathrm{L}^{-1}$, and from 0.54 to $6.7 \mu \mathrm{g} \mathrm{L}^{-1}$, respectively. Among the HAAs, DBAA was present in the highest concentration in the test group except at 5 and $10^{\circ} \mathrm{C}$ on Day 1 . The DBCAA concentration was found to have decreased rapidly at 15 and $20^{\circ} \mathrm{C}$ on Day 5 and Day 20 . The DBAA, TBAA, and DBCAA concentrations increased at all temperatures on Day 10. On Day 20, the DBAA exhibited the highest concentration among the investigated DBPs at all of the investigated temperatures. The DBAN concentration was the highest at all temperatures on Day 1 and Day 10, especially at lower temperatures. The mean DBAN concentration at the lowest water temperature was twice as high as that at the highest water temperature. The DBAN concentration was unstable with respect to storage time at 15 and $20^{\circ} \mathrm{C}$, which is similar to the behavior of DBCAA. Although MBAN was detected at low concentrations, it was detected at high water temperatures.

The DBAA concentrations at all water temperatures were strongly correlated with the storage time (Fig. 5a). The TBAA concentration also tended to increase with increasing storage time, and this tendency was especially apparent at low temperatures (Fig. 5b). The DBCAA concentration tended to increase with increasing storage time at low temperatures, especially at $10^{\circ} \mathrm{C}$; however, the DBCAA concentration was unstable with respect to storage time at high temperatures (Fig. 5c). The concentration of MCAA and BCAA tended to increase with increasing storage time (Fig. 5d, e). In particular, the concentration of MCAA was statistically significant at 10 and $20^{\circ} \mathrm{C}$, and the BCAA concentration was statistically significant at the other water temperatures except for $15^{\circ} \mathrm{C}$. The DBAN concentrations tended to decrease over time at low temperatures, but the change in concentration was not statistically significant (Fig. 5f). By contrast, the concentration of DBAN remained high until 20 days at low water temperatures (Fig. 4d). The concentrations of the HAAs and HANs did not show statistically significant changes with water temperature during the test period.

The average composition ratios of brominated HAAs at all storage times was $44.3 \%$ for DBAA, followed by $29.8 \%$ for TBAA and $19.9 \%$ for DBCAA; the composition ratios of the chlorinated HAA, MCAA, and BCAA were low (Fig. 6a). This trend is similar to that of the composition ratio at various temperatures (not shown). The composition of DBAA increased with increasing storage time; however, the compositions of DBCAA and TBAA decreased. Also, the number of different HAA species tended to increase at 20 days. DBAN accounted for more than $70 \%$ of the HANs, including $92 \%$ at low water temperatures (Fig. 6b). In the case of high water temperatures, the DBAN composition ratio decreased to $64 \%$ and the MBAN composition ratio increased to $32 \%$.

\section{Environmental risk assessment using MAMPEC}

The MAMPEC results for a simple environmental risk assessment were evaluated for the DBPs; the highest concentration of each DBP in each test was used in the
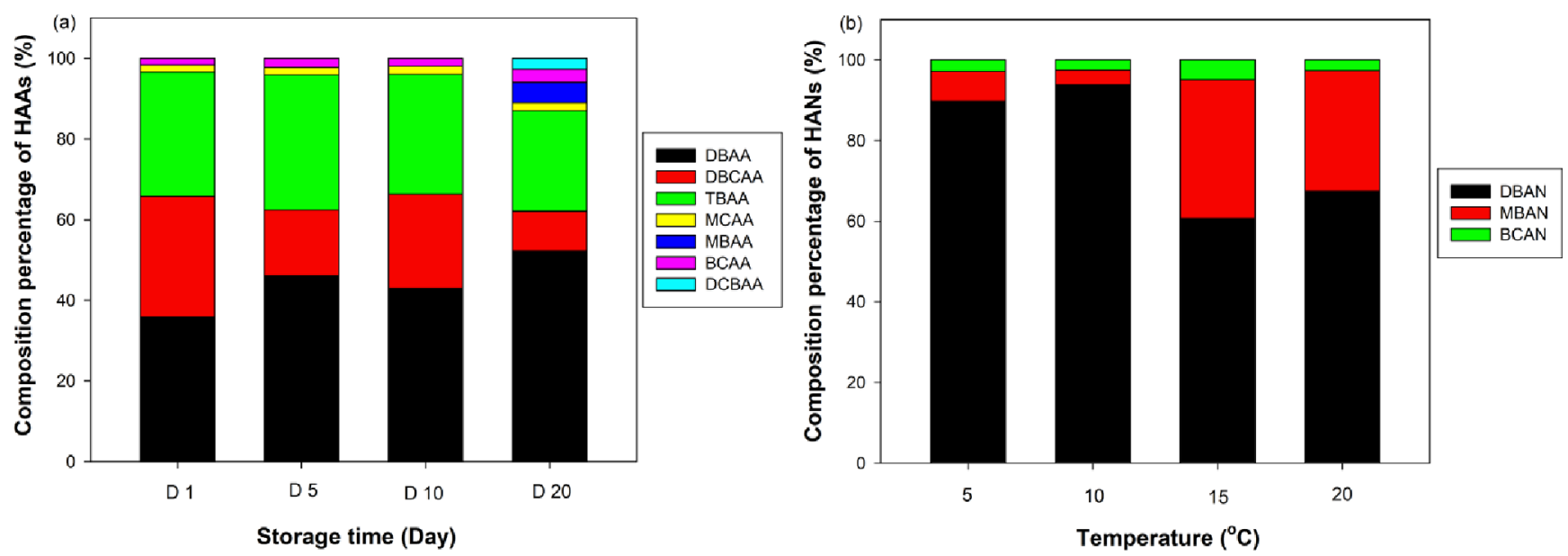

Fig. 6. The composition percentages of (a) HAAs at various storage times and (b) HANs at various water temperatures. (DBAA: dibromoacetic acid, DBCAA: dibromochloroacetic acid, TBAA tribromoacetic acid, MCAA: monochloroacetic acid, MBAA: monobromoacetic acid, BCAA: bromochloroacetic acid, DCBAA: dichlorobromoacetic acid, DBAN: dibromoacetonitrile, MBAN: monobromoacetonitrile, BCAN: bromochloroacetonitrile) 
Table 2. The predicted environmental concentration (PEC) at surrounding (near ship) conditions, as calculated from MAMPEC 3.1, the predicted no-effect concentration (PNEC) values, as calculated from lowest toxicity data and the assessment factor (AF), and the PEC/PNEC ratios of HAAs and HANs detected in this study

\begin{tabular}{ccccccccc}
\hline \hline $\begin{array}{c}\text { DBP } \\
\text { compound }\end{array}$ & $\begin{array}{c}\text { Time } \\
(\text { days })\end{array}$ & $\begin{array}{c}\text { Temp. } \\
\left({ }^{\circ} \mathrm{C}\right)\end{array}$ & $\begin{array}{c}\text { PEC general } \\
\left(\mu \mathrm{g} \mathrm{L}^{-1}\right)\end{array}$ & $\begin{array}{c}\text { PEC near ship } \\
\left(\mu \mathrm{g} \mathrm{L}^{-1}\right)\end{array}$ & $\begin{array}{c}\text { PNEC general } \\
\left(\mu \mathrm{g} \mathrm{L}^{-1}\right)\end{array}$ & $\begin{array}{c}\text { PNEC near ship } \\
\left(\mu \mathrm{g} \mathrm{L}^{-1}\right)\end{array}$ & $\begin{array}{c}\text { PEC/PNEC } \\
\text { general }\end{array}$ & $\begin{array}{c}\text { PEC/PNEC } \\
\text { near ship }\end{array}$ \\
\hline BCAA & 20 & 15 & 0.078 & 0.955 & 16 & 16 & 0.005 & 0.060 \\
DBAA & 20 & 10 & 1.02 & 12.4 & 6900 & 6900 & 0.000 & 0.002 \\
DBCAA & 20 & 10 & 0.385 & 4.71 & 300 & 300 & 0.001 & 0.016 \\
DCBAA & 20 & 10 & 0.056 & 0.686 & 60 & 100 & 0.001 & 0.007 \\
MBAA & 20 & 10 & 0.126 & 1.55 & 16 & 16 & 0.008 & 0.097 \\
MCAA & 20 & 20 & 0.047 & 0.58 & 0.58 & 0.58 & 0.082 & 1.000 \\
TBAA & 20 & 10 & 0.552 & 6.76 & 14000 & 22000 & 0.000 & 0.000 \\
BCAN & 1 & 20 & 0.009 & 0.261 & 0.69 & 6.9 & 0.014 & 0.038 \\
DBAN & 10 & 20 & 0.717 & 8.79 & 0.06 & 0.55 & 13.0 & 16.0 \\
MBAN & 1 & 15 & 0.058 & 1.44 & 0.16 & 230 & 0.005 & 0.006 \\
\hline
\end{tabular}

*The value of PNEC in general and near ship is quoted from GISIS (http://gisis.imo.org/public/BWC/Chemical/ChemicalList.aspx)

model (Table 2). Among the HAAs, MCAA showed a PEC/ PNEC ratio (near ship) of 1 , which is the criterion for judging the effect on the port ecosystem (Table 2). The maximum concentration of MCAA was low $\left(2.8 \mu \mathrm{g} \mathrm{L} \mathrm{L}^{-1}\right)$; however, the PNEC (near ship) was also low (0.58) because of its high toxicity. The PEC/PNEC ratio of the other HAAs did not exceed 1. DBAA showed the highest concentration $(60.1 \mu \mathrm{g}$ $\mathrm{L}^{-1}$ ) among the HAAs; however, the PEC/PNEC ratio in general and near ship did not exceed 1 because of its low toxicity. The PEC/PNEC ratios of DBAN in general and near ship were 13.0 and 16.0 at the highest concentration and 0.855 and 1.047 at the lowest concentration in this study.

\section{Discussion}

The TRO concentration decreased approximately $60 \%$ at all water temperatures on Day 1 and rapidly decreased at $20^{\circ} \mathrm{C}$ over time (Fig. 1). However, the residual TRO concentration was measured until 20 days in all test groups, and it was 1.78 $\mathrm{mg} \mathrm{L} \mathrm{L}^{-1}$ even after 20 days at $5^{\circ} \mathrm{C}$. TRO consumption was accelerated as the temperature was increased from $5^{\circ} \mathrm{C}$ to $20^{\circ} \mathrm{C}$, similar to the results of Roccaro et al. (2008). The residual TRO concentration indicates that the treated ballast water would continue to sterilize organisms in the storage tank of a ship, which means that DBPs would also continue to be generated. In tests where additional additives were introduced, TRO consumption by added phytoplankton appeared minimal (Fig. 2b); however, the TRO concentration in the glucoseadded seawater decayed substantially faster than in the control sample (Fig. 2b), similar to the results of Duan et al. (2016).
However, unlike the results of the present study, Lee et al. (2017) reported that TRO was not significantly consumed by glucose in ballasting water.

Both the DON and DIN concentrations were highest at 10 days in all of the treatments (Fig. 1b and c). We speculated that this trend was related to the organic decomposition process of the killed organisms. In tests where additional additives were introduced, the increase in DON concentration in the experiments with filtered seawater with phytoplankton added (Groups 3 and 4) was more pronounced than in the other experiments (Fig. 2a), suggesting that the DON source was most likely decomposition of dead phytoplankton rather than the effect of glucose. If dead organisms are a source of DON, then the DON concentration should be high at higher temperatures because decomposition of phytoplankton is rapid at high water temperatures (Conley et al. 2007; Jang et al. 2011). However, a high DON concentration was observed at lower temperatures (Fig. 1b), which indicates that the maximum value of DON differed slightly at different water temperatures. This observation is consistent with the tests involving additives, where the highest concentration of DON appeared at 7 days in Group 4 (Fig. 2a). Because the ballast water treated in the field did not contain added glucose, the residual TRO concentration of the ballast tank in the field should be higher than that in the BWMS approval test. Therefore, if water with a high bioconcentration in a port is treated with a BWMS with active substances and the treated water is stored in the ballast tank for more than 5 days, the DON and the residual TRO will affect the concentration of DBPs in the ballast tank. 
The concentration of major DBPs increased at Day 10 (Fig. 4c), where the DON concentration also increased. As previously mentioned, the DON concentration increased because of decomposition of dead organisms. As a result, we propose that the DON concentration was increased by the new source and then reacted with the remaining residual TRO to increase the concentration of DBPs. In particular, the DBAN concentration also increased on Day 10, which is attributable to DON affecting the formation of DBAN. Lee et al. (2007) suggested that DON can function as a precursor material for nitrogen-DBPs. Keith et al. (1982) also reported that HANs are produced by the reaction of chlorine with a nitrogen-containing compound. The DBAN concentration in the discharge of ballast water may adversely affect the marine environment if the ballast water is treated with a BWMS using active substances in areas with high biomass in winter (e.g., marine environments, brackish water, and freshwater), as such areas are prone to phytoplankton blooms (Litaker et al. 2002; Lee and Han 2007; Baek et al. 2011). Total HAA concentration showed a rapid increase at Day 20 (Fig. 3a). The National Toxicology Program (NTP 2010) has suggested that further chlorination of HANs results in the formation of HAAs. Thus, the HANs can be converted to HAAs by residual chlorine during extended storage. For this reason, the DBAA concentration tended to increase and the DBAN concentration suddenly decreased at $15^{\circ} \mathrm{C}$ and $20^{\circ} \mathrm{C}$ on Day 20 (Fig. 4d). Thus, the positive relationships for storage time and water temperature of major HAAs (Fig. $5 \mathrm{a}-\mathrm{e})$ suggest that their increases in concentration may be related to DON concentration, and the possibility that HANs can be converted to HAAs over time. However, the decrease in DBAN did not affect the increase in HAA concentration at 15 and $20^{\circ} \mathrm{C}$ on Day 5. In the future, studies of the factors that affect DBPs conversion over time will be needed.

The change in DBAA concentration with respect to water temperature shows a significant difference between 5 and $20^{\circ} \mathrm{C}$ (Fig. 5a), which is similar to the results reported by Shah et al. (2015). They reported that DBAA is the dominant brominated HAA in seawater and that its concentration increased more than twofold when the water temperature increased from $4^{\circ}$ to $22^{\circ} \mathrm{C}$. However, there were no significant differences between DBAA concentrations at 10 and $20^{\circ} \mathrm{C}$ (Fig. 5a), indicating no statistically significant correlation between water temperatures, in contrast to the findings of Zhang et al. (2013b). They reported that DBAA increased with increasing temperature from 10 to $30^{\circ} \mathrm{C}$ at $48 \mathrm{~h}$ of storage after treatment, although the retention time mentioned in their paper was different from that used in the present work. DBAN did not show a statistically significant change with storage time and temperature; however, the concentration of DBAN remained relatively high at low temperatures over time. This result is consistent with the temporal variation of DBAN with respect to water temperature characteristics (Zhang etal.2013a), which suggested that DBAN concentration increases with decreasing temperature in seawater from 30 to $10^{\circ} \mathrm{C}$.

The composition ratio of HAAs (Fig. 6a) was similar to ratios reported in the review paper by Kim et al. (2015) (DBAA $38.3 \%$, TBAA $22.4 \%$, and DBCAA $19.6 \%$ ). Kim et al. (2015) also suggested that this pattern is typical for HAA speciation in chlorinated seawater. Yu et al. (2015) reported the formation and speciation of HAA5 (MCAA, MBAA, DCAA, DBAA, and TCAA) for $0.5,12$, and $24 \mathrm{~h}$ in seawater desalination using $\mathrm{ClO}_{2}$ as a disinfectant; the composition ratio and concentration of DBAA increased with increasing storage time and increasing $\mathrm{ClO}_{2}$ concentration. Yu et al. (2015) also reported that MCAA is the major DBP at a low dose of $\mathrm{ClO}_{2}$ or short $\mathrm{ClO}_{2}$ contact time. Yu et al. (2015) and Shah et al. (2015) reported that the concentrations of most of the HAAs exhibited their greatest increase before $24 \mathrm{~h}$ and that either no increase or a gradual increase in concentration was subsequently observed at 3 days and 5 days, respectively. The results also showed similar results until 5 days; however, the HAA concentrations measured in this study increased rapidly after 5 days (Fig. 3a), which may be related to the newly supplied DOM from the decomposition of organic matter (e.g., phytoplankton) after 5 days (Figs. 1b, 2a). Also, the increase in the composition ofDBAA may be associated with the decrease in the composition of DBAN on Day 20 (Fig. 6) due to the conversion of HAN to HAA over time (NTP 2010).

The MAMPEC results suggest that, on the basis of their PEC/PNEC ratios, DBAN and MCAA are more likely to be harmful to the marine ecosystem. The main reason for this result is that the PNEC values are low because of the high toxicity of the two substances. However, because of the lack of information about the toxicity of DBAN toward marine organisms, a low PNEC was used; thus, the PEC/PNEC ratio may be erroneously high. Thus, toxicity tests for DBAN on marine organisms are needed. As of January, 2019, the IMO has granted final approval to 40 BWMSs that use active substances (IMO2019). The documents submitted to the IMO for final approvals of these BWMSs indicate that MCAA and 
DBAN were detected in the discharge water of 11 of the BWMSs. The documents for seven of the BWMSs mention only MCAA, and the documents for eight of the BWMSs mention only DBAN. Among them, MCAA was detected in the discharge water of two BWMSs, and DBAN was detected in the discharge water of $12 \mathrm{BWMSs}$ in cases where the PEC/PNEC general value exceeds 1 . Among the nine documents mentioning the PEC/PNEC near ship, the ratios for MCAA and DBAN exceeded 1 in two and six documents, respectively.

Australia has implemented MAMPEC by using actual values for the conditions at three Australian ports instead of the default conditions as inputs for the MAMPEC (IMO 2018b). Using data provided by IMO GISIS, they predicted that most DBPs would likely be below their PNEC but that DBAN and MCAA could potentially exceed the predicted PNEC. In the present study, DBAN, MCAA, and DBAA have also been found to be potentially hazardous to the environment. Zhang et al. (2014), who performed a risk assessment of marine environments for BWMSs, also reported that the PEC/PNEC ratio of MCAA exceeded 1.

Woo et al. (2002) analyzed 209 DBPs considered in a structure-relationship analysis (SRA) evaluation in relation to concerns about cancer; 20 of the DBPs were of priority concern, with a moderate or high-moderate rating. Among these 20, the six N-DBPs are suitable priority candidates for future carcinogenicity testing and/or mechanistic studies. The concern levels for the BCAN,DBAN, and MBAN measured in our study are moderate (likely to be target carcinogens at low doses), low-moderate (likely to be weakly target carcinogens at relatively high doses), and low-moderate, respectively. Muellner (2007) analyzed seven HANs using microplatebased Chinese hamster ovary cell assays for chronic cytotoxicity and acute genotoxicity. Among these seven HANs, DBAN $(2.8 \mu \mathrm{M})$ showed the greatest potential for chronic cytotoxicity and DBAN $(47 \mu \mathrm{M})$ exhibited the second-highest acute genotoxicity. Most previous studies on the formation and control of N-DBPs have focused on wastewater treatment systems, power plants, and drinking-water treatment utilities that use surface-water sources; by contrast, limited research has focused on N-DBPs created in BWMSs that use an active substance to treat seawater and brackish water. Seawater includes a high bromide ion that ranges from 50,000 to $80,000 \mathrm{~m} \mathrm{~L} \mathrm{~L}^{-1}$, which enhances the formation of brominated DBPs, which are known to be much more cytotoxic and genotoxic than their chlorinated analogues (Richardson et al. 2007; Delacroix et al. 2013). In particular, brominated HANs are considered to be potentially more active than chlorinated HANs (NTP 2010; Mueller et al. 2007). The persistence and fate of brominated DBPs discharged into coastal or estuarine ecosystems are also not well-known (Gonsior et al. 2015). Another important factor in risk assessment considers the cocktail effect from the simultaneous release of such a large range of DBPs. Thus, an urgent need exists to study the effect on marine ecosystem of N-DBPs and Br-DBPs formed when BWMSs that use active substances are applied in seawater and brackish water.

\section{Conclusions}

BWMSs that use active substances are to be installed on international ships between 2019 and 2024. Thus, DBPs formed by BWMSs that use active substances will be increasingly discharged into the waters of international ports, and their toxicity can further affect the marine ecosystem via the cocktail effect. In this study, the following conclusions were obtained:

A longer ballast-water storage time leads to an increased concentration of total HAAs. In particular, when the ballast water is treated in a port with a high biological concentration, their concentration can be dramatically increased.

Further studies on DOM content (including DON) related to N-DBP formation should be conducted in the future. At the point of increasing DON in this study, the DBAN concentration was the highest for all water temperatures.

MCAA may negatively affect the marine environment when the storage time is long and the water temperature is high in ballast tanks.

DBAN may negatively affect the marine environment when the water temperature is low in ballast tanks.

A study of the toxicity ofDBAN toward marine organisms is needed. With toxicity information for DBANs more available, the environmental risks can be better assessed by more realistic calculations of PEC / PNEC values.

MCAA and DBAN were assessed as having high environmental risks and DBAA could be present at the highest concentrations in the ballast water discharge treated with a BWMS.

\section{Acknowledgements}

This study was supported by a research projected titled 
"Development of ICT-based PSC countermeasure technology and core equipment for implementation of IMO Ballast Water Management Convention" from the Korea Institute of Marine Science \& Technology Promotion, Republic of Korea (PM61820).

\section{References}

Baek SH, Ki JS, Katano T (2011) Dense winter bloom of the dinoflagellate Heterocapsa triquetra below the thick surface ice of brackish Lake Shihwa, Korea. Phycol Res 59:273-285. doi:10.1111/j.1440-1835.2011.00626.x

Cha HG, Seo MH, Lee HY (2015) Enhancing the efficacy of electrolytic chlorination for ballastwater treatment by adding carbon dioxide. Mar Pollut Bull 95:315-323. doi:10.1016/ j.marpolbul.2015.03.025

Choi KH, Kimmerer W, Smith G (2005) Post-exchange zooplankton in ballast water of ships entering the San Francisco Estuary. J Plankton Res 27:707-714. doi:10.1093/plankt/fbi044

Conley DJ, Carstensen JM, Ertebjerg G, Christensen PB, Dalsgaard T, Hansen JLS, Josefson AB (2007) Long-term changes and impacts of hypoxia in Danish coastal waters. Ecol Appl 17(5):S165S184. doi:10.1890/05-0766.1

David M, Linders J, Gollasch S (2018) Is the aquatic environment sufficiently protected from chemicals discharged with treated ballast water from vessels worldwide? - A decadal environmental perspective and risk assessment. Chemosphere 207:590-600. doi:10.1016/j.chemosphere.2018.05.136

Delacroix S, Vogelsang C, Tobiesen A (2013) Disinfection by-products and ecotoxicity of ballast water after oxidative treatment Results and experiences from seven years of full-scale testing of ballast water management systems. Mar Pollut Bull 73:2436. doi:10.1016/j.marpolbul.2013.06.014

Drillet G, Schmoker C, Trottet A (2013) Effects of temperature on type approval testing of ballast water treatment systems. Integr Environ Assess 9:192-195. doi:10.1002/ieam.1394

Duan D, Liu G, Yao P (2016) The effects of organic compounds on inactivation efficacy of Artemia salina by neutral electrolyzed water. Ocean Eng 125:31-37. doi:10.1016/j.oceaneng.2016. 08.003

Endresen Ø, Behrens HL, Brynestad S (2004) Challenges in global ballast water management. Mar Pollut Bull 48:615-623. doi:10.1016/j.marpolbul.2004.01.016

Gollasch S (2006) Overview on introduced aquatic species in European navigational and adjacent waters. Helgoland Mar Res 60:84-89. doi:10.1007/s10152-006-0022-y

Gonsior M, Mitchelmore C, Heyes A (2015) Bromination of marine dissolved organic matter following full scale electrochemical ballast water disinfection. Environ Sci Technol 49:9048-9055. doi:10.1021/acs.est.5b01474
Hallegraeff GM, Bolch CJ (1991) Transport of toxic dinoflagellate cysts via ships' ballast water. Mar Pollut Bull 22:27-30. doi:10.1016/0025-326X(91)90441-T

Hua G, Reckhow D, Kim J (2006) Effect of bromide and iodide ions on the formation and speciation of disinfection byproducts during chlorination. Environ Sci Technol 40:3050-3056. doi:10.1021/es0519278

Hyun B, Baek SH, Shin K, Choi KH (2017) Assessment of phytoplankton invasion risks in the ballast water of international ships in different growth conditions. Aquat Ecosyst Health 20:423-434. doi:10.1080/14634988.2017.1406273

IMO (2004) International convention for the control and management of ship's ballast water and sediment (BWM/CONF/36). International Maritime Organization. https://docs.imo.org/ Documents/Detail.aspx?did=24103 Accessed 26 Feb 2020

IMO (2008) Procedure for approval of ballast water management systems that make use of active substances (G9) (MEPC57/21). International Maritime Organization. https:/docs.imo.org/ Documents/Detail.aspx?did=49934 Accessed 6 Feb 2020

IMO (2018a) Code for approval of ballast water management systems (BWMS CODE) (Resolution 300(72)). International Maritime Organization. https://docs.imo.org/Documents/Detail. aspx?did=110918 Accessed 6 Feb 2020

IMO (2018b) Outcomes of modeling of environmental concentrations of disinfection by-products in Australian port environments (PPR 6/INF.9). https://docs.imo.org/Documents/Detail.aspx?did= 113972 Accessed 6 Feb 2020

IMO (2019) List of ballast water management systems that make use of active substances which received basic and final approval (BWM.2/Circ.34/Rev.7). International Maritime Organization. https://docs.imo.org/Documents/Detail.aspx?did=114298 Accessed 6 Feb 2020

Jang PG Hyen BG, Jang MC, Shin K (2016) A study of characteristics on water quality and phytoplankton in ship's ballast water originating from international ports of China. J Korean Soc Mar Environ Saf 22(7):821-828. doi:10.7837/kosomes.2016. 22.7.821

Jang PG, Shin K, Chang M, Dongseon Kim (2011) Spatial and temporal trends in water quality in response to sewage discharge in Masan and Hangam Bays, Korea. J Coastal Res 27(6A): 144-155. doi:10.2112/JCOASTRES-D-11-00023.1

Keith LH, Hall RC, Hanisch RC, Landolt RG, Henderson JE (1982) New methods for analyzing water pollutants. Water Sci Technol 14:59-71. doi:10.2166/wst.1982.0087

Kim D, Amy GL, Karanfil T (2015) Disinfection by-product formation during seawater desalination: A review. Water Res 81:343355. doi:10.1016/j.watres.2015.05.040

Lee JY, Han MS (2007) Change of blooming pattern and population dynamics of phytoplankton in Masan Bay, Korea. J Oceanogr Soc Korea 12:147-158

Lee J, Shon MB, Cha HG (2017) The impact of adding organic 
carbon on the concentrations of total residual oxidants and disinfection by-products in approval tests for ballast water management systems. Sci Total Environ 605-606:852-859. doi:10.1016/j.scitotenv.2017.06.263

Lee W, Westrehoff P, Croué JP (2007) Dissolved organic nitrogen as a precursor for chloroform, dichloroacetonitrile, $\mathrm{N}$-Nitrosodimethylamine, and trichloronitromethane. Environ Sci Technol 41:5485-5490. doi:10.1021/es070411g

Liltved H, Vogelsang C, Modahl I, Dannevig B (2006) High resistance of fish pathogenic viruses to UV irradiation and ozonated seawater. Aquacult Eng 34:72-82. doi:10.1016/j.aquaeng. 2005.05.002

Litaker RW, Tester PA, Duke CS, Kenney BE, Pinckney JL, Ramus J (2002) Seasonal niche strategy of the bloom-forming dinoflagellate Heterocapsa triquetra. Mar Ecol-Prog Ser 232:45-62. doi: 10.3354/meps 232045

Liu ZQ, Shah AD, Salhi E (2018) Formation of brominated trihalomethanes during chlorination or ozonation of natural organic matter extracts and model compounds in saline water. Water Res 143:492-502. doi:10.1016/j.watres.2018.06.042

MEPC (2014) Information on the GESAMP-BWWG database of chemicals most commonly associated with treated ballast water (MEPC 67/INF17). Marine Environmental Protection Committee. https://docs.imo.org/Documents/Detail.aspx?did=88063 Accessed 26 Feb 2020

Muellner MG, Wagner ED, McCalla K (2007) Haloacetonitriles vs. regulated haloacetic acids: Are nitrogen-containing DBPs more Ttxic? Environ Sci Technol 41:645-651. doi:10.1021/ es0617441

NTP (2010) Toxicology and carcinogenesis studies of dibromoacetonitrile (CAS No. 3252-43-5) in F344/N rates and B6C3F1 mice (drinking water studies). National Toxicology Program. https://ntp.niehs. nih.gov/publications/reports/tr/500s/tr544/index.html?utm source $=$ direct\&utm_medium $=$ prod\&utm_campaign $=$ ntpgoli nks\&utm_term $=$ tr544abs Accessed 26 Feb 2020

Park C, Cha HG, Lee JH (2017) The effects of chemical additives on the production of disinfection byproducts and ecotoxicity in simulated ballast water. J Sea Res 129:80-88. doi:10.1016/ j.seares.2017.07.005

PimentelD, Zuniga R, Morrison D (2005) Update on the environmental and economic costs associated with alien-invasive species in the United States. Ecol Econ 52:273-288. doi:10.1016/j.ecolecon. 2004.10.002

Richardson SD, Plewa MJ, Wagner ED, Schoeny R, DeMarini DM (2007) Occurrence, genotoxicity, and carcinogenicity of regulated and emerging disinfection by-products in drinking water: A review and roadmap for research. Mutat Res 636:178-242. doi:10.1016/j.mrrev.2007.09.001

Roccaro P, Chang HS, Vagliasindi FGA (2008) Differential absorbance study of effects of temperature on chlorine consumption and formation of disinfection by-products in chlorinated water. Water Res 42:1879-1888. doi:10.1016/j.watres.2007.11.013

Shah AD, Liu ZQ, Salhi E (2015) Formation of disinfection byproducts during ballast water treatment with ozone, chlorine, and peracetic acid: Influence of water quality parameters. Environ Sci-Wat Res Technol 1:465-480. doi:10.1039/C5EW00061K

von Guntten U (2018) Oxidation processes in water treatment: Are we on track? Environ Sci Technol 52:5062-5075. doi:10.1021/ acs.est. 8 b00586

Werschkun B, Banerji S, Basurko OC, David M, Fuhr F, Gollasch S (2014) Emerging risks from ballast water treatment: The run-up to the international ballast water management convention. Chemosphere 112:256-266. doi:10.1016/j.chemosphere.2014. 03.135

Westerhoff P, Chao P, Mash H (2004) Reactivity of natural organic matter with aqueous chlorine and bromide. Water Res 38(6): 1502-1513. doi:10.1016/j.watres.2003.12.014

Woo YT, Lai D, McLain JL (2002) Use of mechanism-based structure-activity relationships analysis in carcinogenic potential ranking for drinking water disinfection by-products. Environ Health Persp 110:75-87. doi:10.1289/ehp.02110s175

Yu HW, Oh SG, Kim IS (2015) Formation and speciation of haloacetic acids in seawater desalination using chlorine dioxide as disinfectant. J Ind Eng Chem 26:193-201. doi:10.1016/j.jiec. 2014.10.046

Zhang N, Ma B, Li J (2013a) Factors affecting formation of chemical by-products during ballast water treatment based on an advanced oxidation process. Chem Eng J 231:427-433. doi:10.1016/ j.cej.2013.07.055

Zhang N, Zhang Y, Bai M, Zhang Z, Chen C, Meng X (2014) Risk assessment of marine environments from ballast water discharges with laboratory-scale hydroxyl radicals treatment in Tianjin Harbor, China. J Environ Manage 145:122-128. doi:10.1016/ j.jenvman.2014.06.022

Zhang XL, Yang HW, Wang XM (2013b) Formation of disinfection by-products: Effect of temperature and kinetic modeling. Chemosphere 90:634-639. doi:10.1016/j.chemosphere.2012. 08.060

Publisher's Note Springer Nature remains neutral with regard to jurisdictional claims in published maps and institutional affiliations. 